Bangladesh J. Bot. 48(2): 387-394, 2019 (June)

\title{
EFFECTS OF POTASSIUM FERTILIZATION ON RADIOCAESIUM TRANSFER FROM SANDY SOIL TO BARLEY (HORDEUM VULGARE L.)
}

\author{
SM Soliman, Ahmed A Moursy* and HS Eissab ${ }^{1}$ \\ Soils and Water Research Department, Nuclear Research Center, \\ Atomic Energy Authority, P.O. 13759, Egypt
}

Keywords: Potassium fertilization, Barley plants, Radiocesium uptake, Transfer factor, Discrimination factor

\begin{abstract}
Uptake and translocation of radiocesium artificially added to sand soil cultivated with barley as affected by different rates of potassium were traced in outdoor pot experiment. Experimental soil was contaminated with 0.01 and $0.1 \mathrm{mM}{ }^{137} \mathrm{Cs}$ equal to $(200$ and $400 \mathrm{~Bq} / \mathrm{kg})$ in the form of $\mathrm{CsCl}$ and incubated for 14 days prior to 150 days plant growth period. The transfer factor (TF) average values from soil-to-total biomass were found to range from 0.40 up to 0.53 as affected by interaction between tested treatments. Increasing $\mathrm{K}$ rates from 125 to $250 \mathrm{~kg} / \mathrm{ha}$ markedly reduced the mean averages of TFs of ${ }^{137} \mathrm{Cs}$ from soil-to-roots by about 24 to $68 \%$, respectively and from soil-to-total biomass by about 36 and $74 \%$, respectively lower than corresponding control. In all cases, the discrimination factor was below unity, indicating that Cs is less efficiently absorbed from soil than its nutrient analogue $\mathrm{K}$.
\end{abstract}

\section{Introduction}

Soil contamination with radiocesium has a long term radiological impact due to its long physical half-life (30 years of ${ }^{137} \mathrm{Cs}$ and 2 years of ${ }^{134} \mathrm{Cs}$ ) and its high biological availability. Due to its chemical properties, ${ }^{137} \mathrm{Cs}$ is readily soluble in water, and, in solution, and more easily absorbed by plants than native stable ${ }^{133} \mathrm{Cs}$ in the soil because a part of the ${ }^{133} \mathrm{Cs}$ is in a soil structure where it is hard to replace with ${ }^{137} \mathrm{Cs}$. Due to the chemical similarities with potassium, it enters the food chain pathway and may cause a health hazard to humans (Chino et al.2011). Plant consumption, either as direct foodstuff or indirectly as animal foodstuff, is a major pathway for radiocesium incorporation. In fact, its content in foodstuff has been controlled since the Chernobyl accident happened, with temporary permissive limits for different foodstuff after an emergency (Hamada 2012). In the environment, radiocesium is mainly present in soil solution as a free hydrated cation $\left({ }^{137} \mathrm{Cs}^{+}\right)$with little or no tendency to form soluble complexes. Barley plant after maize and wheat contamination of the edible parts. The chemical-physical characteristics of the soil, root interception, ion uptake by roots, ion transport, ion translocation, remobilization of mineral nutrients, and root exudation are some of the factors affecting the transfer of radionuclides from soil to plants. The soil-to-plant transfer factor is regarded as one of the most important parameters in environmental safety assessment needed for nuclear facilities. This parameter is necessary for environmental transfer models which are useful in prediction of the radionuclide concentrations in agriculture crops for estimating dose intake by humans (IAEA 1994).

Transfer factor (TF) is defined as the ratio of radionuclide concentrations transfer vegetation and soil. The soil-to-plant transfer factor is an important parameter widely used to evaluate food chain transfer. However, for a number of long-lived radionuclides it varies by up to three orders of magnitude. This can be explained by chemical, biological, hydrological, physical peculiarities of the soil, or by variety of plant physiological processes (Ehlken and Kirchner 2002). Radionuclide

*Author for correspondence: <ahmad1a2m3@yahoo.com>. ${ }^{1}$ Protection Department, Nuclear Research Center, Atomic Energy Authority, P.O. 13759, Egypt. 
transfer depends on landscape and vegetation, and soil as well as on the amount of a radionuclide, its chemical properties and meteorological conditions during the fallout (Yoshida et al. 2004). It is well established that TFs vary widely among crops and soils, i.e., the values are region-specific, and soil-plant TFs decrease with time after contamination. Compilation of TFs of ${ }^{137} \mathrm{Cs}$ illustrates that they vary by 3 orders of magnitude for the same plant ( IAEA 2009) even in controlled comparative studies that, for example, assessed the effect of soil properties only (Smolders 1997). Cesium uptake is inhibited when the potassium concentration in soil solution increases (Waegeneers et al. 2009). Thus, potassium fertilizers are effective counter measure, especially on nutrient poor soils with low K status (Smolders 1997) and low degree of base saturation (Rosén et al.2011). Thus, the application of fertilizers containing potassium at elevated rates is one of the most effective countermeasures for reducing radiocesium uptake (Perepelyatnikov et al. 2007). The purpose of this work was to examine the concentration levels of ${ }^{137} \mathrm{Cs}$ and $\mathrm{K}$ application on the radiocaesium soil-to-barley plant transfer and uptake under sandy soil condition.

\section{Materials and Methods}

The experiment was carried out with outdoor potted plants in Soils and Water Research Department farm, Nuclear Research Center, Inshas, Egypt. Sand soil samples were collected from Inshas area at a depth of $0-30 \mathrm{~cm}$. It was air-dried, ground and screened to pass through a $2.0 \mathrm{~mm}$ sieve. Chemical and physical properties of the experimental soil were determined according to Page et al. (1982) and the results are presented below. Some physical and chemical properties of the soil used.

A - Course sand 64.1\%; Fine sand 26.4\%; Silt 2.7\%; Clay 6.8\%; Textural class (Sand).

\begin{tabular}{|c|c|c|c|c|c|c|c|}
\hline \multicolumn{4}{|c|}{ Cations } & \multicolumn{4}{|c|}{ Anions } \\
\hline $\mathrm{Ca}^{2+}$ & $\mathrm{Mg}^{2+}$ & $\mathrm{Na}^{+}$ & $\mathrm{K}^{+}$ & $\mathrm{CO}^{2-}$ & $\mathrm{HCO}^{3-}$ & $\mathrm{Cl}^{-}$ & $\mathrm{SO}_{4}^{2}$ \\
\hline 1.25 & 1.00 & 0.32 & 0.09 & --.- & 0.88 & 1.25 & 0.53 \\
\hline
\end{tabular}

B - Chemical properties of the investigated soil.

$\mathrm{C}-\mathrm{pH}\left(1: 2.5\right.$ soil suspension), $\mathrm{EC}$ (paste extract), organic matter $(\mathrm{OM})$, total $\mathrm{N}(\mathrm{TN})$ ratio and $\mathrm{CaCO}_{3}$ content.

\begin{tabular}{cccccc}
\hline $\mathrm{pH}(1: 2.5) 2.5)$ & $\mathrm{EC}\left(\mathrm{dSm}^{-1}\right)$ & $\mathrm{OC} \mathrm{gkg}^{-1}$ & $\mathrm{OM} \mathrm{gkg}^{-1}$ & $\mathrm{TN} \mathrm{gkg}^{-1}$ & $\mathrm{CaCO}_{3} \mathrm{gkg}^{-1}$ \\
\hline 7.97 & 0.27 & 0.17 & 0.3 & 0.007 & 10.0 \\
\hline
\end{tabular}

Liquid solution of 0.01 and $0.1 \mathrm{mM}$ equal to about 200 and $400 \mathrm{~Bq}$ of carrier-free ${ }^{137} \mathrm{Cs}$ was added as ${ }^{137} \mathrm{CsCl}$, respectively and thoroughly mixed with $10 \mathrm{~kg}$ sand soil pot. The recommended field rate $(100 \mathrm{~kg} / \mathrm{ha})$ equal to $41.67 \mathrm{mg} /$ pot of single superphosphate $\left(15.5 \% \mathrm{P}_{2} \mathrm{O}_{5}\right)$ was added to the soils for each pot before sowing of barley seeds; while, $\left(\mathrm{NH}_{4}\right)_{2} \mathrm{SO}_{4}$ as a source of $\mathrm{N}$ was applied at rate of $(523.2 \mathrm{~kg} / \mathrm{ha}$ ) equal to $218 \mathrm{mg} /$ pot at two stages, one at early vegetative stage and the rest before flowering. $\mathrm{K}_{2} \mathrm{SO}_{4}(48 \%)$ was applied at rates of 125 and $250 \mathrm{~kg} / \mathrm{ha}$ (equal to 52.08 and $104.17 \mathrm{mg} /$ pot soil were watered so as to reach about the water holding capacity. The treatments were replicated three times and the experiment was arranged in a completely randomized block design. At maturity, (day-150), plants were harvested and separated into roots; straw and grains. Soils from each pot were collected. Plant and soil samples were dried at 70 and $105^{\circ} \mathrm{C}$, respectively, then ground, sieved and prepared for analysis. The dry weight of each part was recorded $\mathrm{Cs}^{+}$and $\mathrm{K}^{+}$concentrations in both crop and soil samples were measured using ICP 
mass spectrometry. Measurement of $\gamma$-ray activities were made with a Nucleus-Tennlec apparatus with a $70.3 \mathrm{~cm}^{3}$ active volume of high purity Germanium detector, coupled to a nuclear data (ND) multichannel analyzer with Tc-243 amplifiers and ND, Analog-to-Digital Converter (ADC). In addition, a correction factor for random summing effects was calculated and applied following the procedure after Kratochvil et al. (1986).

The soil-to-plant (TF) is the index of the ability of a plant to take up or accumulate activity from soil. It can be obtained dividing the activity concentration in plants by the activity concentration in soil according to the following equation (IUR 1994).

\section{$\mathrm{TF}=($ Activity of radiocesium in plant dry weight $\mathrm{Bq} / \mathrm{kg})$}

(Activity of radiocesium in dry weight soil $\mathrm{Bq} / \mathrm{kg}$ )

In order to examine the relationship between $\mathrm{Cs}^{+}$and $\mathrm{K}^{+}$ions in plants the discrimination factor was used, according to the following equation (Ciuffo et al. 2003). The $\mathrm{Cs} / \mathrm{K}$ discrimination factor was defined as follows:

\section{$\mathrm{Cs} / \mathrm{K}$ discrimination factor $=[\mathrm{Cs}] /[\mathrm{K}]$ in plants \\ $[\mathrm{Cs}] /[\mathrm{K}]$ in soils}

where $[\mathrm{Cs}]$ is $\mathrm{Cs}$ concentration $(\mathrm{mg} / \mathrm{kg})$ in plants and soils, and $[\mathrm{K}]$ is $\mathrm{K}$ concentration $(\mathrm{mg} / \mathrm{kg})$ in plants and soils.

\section{Results and Discussion}

Increasing activity concentration of $\mathrm{CsCl}$ traced with ${ }^{137} \mathrm{Cs}$ from 0.01 to $0.1 \mathrm{mM}$ (200 to 400 $\mathrm{Bq} / \mathrm{kg}$ ) resulted in increase of ${ }^{137} \mathrm{Cs}$ content in different plant parts (Table 1). On the other hand, it tends to decrease with increasing $\mathrm{K}$ levels. Also, it is obvious that roots of barley plantsaccumulated more ${ }^{137} \mathrm{Cs}$ activity concentration than straw or grain. The concentration of radio cesium in barley plants was correlated with those in the soil. In this concern, the average values were $60.05,27.81$ and $10.19 \mathrm{~Bq} / \mathrm{kg}$ for roots, straw and grains, respectively. ${ }^{137} \mathrm{Cs}$ content in the above-ground parts was increased with increasing ${ }^{137} \mathrm{Cs}$ concentration in the soil. The average activity concentration of ${ }^{137} \mathrm{Cs}$ reduced from 98.09 to $31.68 \mathrm{~Bq} / \mathrm{kg}$ for total biomass, while, it reached from 192.91 up to $268.14 \mathrm{~Bq} / \mathrm{kg}$ remained in soil with increasing $\mathrm{K}$ fertilization up to 250 $\mathrm{kg} / \mathrm{ha}$. The highest ${ }^{137} \mathrm{Cs}$ content of total biomass plant and those remained in soil were 139.09 and $260.91 \mathrm{~Bq} / \mathrm{kg}$, when ${ }^{137} \mathrm{Cs}$ was added at rate of $0.1 \mathrm{mM}$. In accordance, many previous physiological experiments have indicated that high $\mathrm{K}^{+}$concentration in the rhizosphere could reduce $\mathrm{Cs}^{+}$absorption by the roots in several plant species (Robison et al. 2009). This reduction was thought to be due to similarity of chemical properties of $\mathrm{K}^{+}$and $\mathrm{Cs}^{+}$. Because they are both alkali metals, $\mathrm{Cs}^{+}$is assumed to enter the root cells through the $\mathrm{K}$ transport apparatus, which is where the competition between these elements is thought to occur. Increasing $\mathrm{K}^{+}$applied to soil from 125 up to $250 \mathrm{~kg} / \mathrm{ha}$ caused markedly reduced ${ }^{137} \mathrm{Cs}$ content in different parts of barley plants in the presence of two levels of ${ }^{137} \mathrm{CsCl}$. In this respect, the relative decrements of ${ }^{137} \mathrm{Cs}$ content were approximately accounted for 13 and $58.4 \%$ in roots; 37.5 and $78 \%$ in straw; 48,2 and $89.2 \%$ in grains less than control at rates of 125 and $250 \mathrm{~kg} \mathrm{~K} / \mathrm{ha}$, respectively. This may be attributed to the lower activity concentration for cereal grain than straw, since cesium behaves similar to potassium. Waegeneers et al. (2009) found that cesium uptake was inhibited with increasing potassium concentration in soil solution. Thus, the application of fertilizers containing potassium at elevated rates is one of the most effective counter measures for reducing radiocesium uptake (Perepelyatnikov et al. 2007, Kobayashi et al. 2016). Marschner, and Marschner (2012) provided evidence for the presence of two distinct pathways for root $\mathrm{K}^{+}$uptake. One system of low selectivity for $\mathrm{Cs}^{+}, \mathrm{Rb}^{+}$and $\mathrm{K}^{+}$, a carrier mediated transporter, which operates at low external concentration of $\mathrm{K}^{+}$, probably driven by cation symport with $\mathrm{H}^{+}$. A second system highly selective 
for $\mathrm{K}^{+}$, channel mediated, which operates at high external $\mathrm{K}^{+}$concentration. Also, lower ${ }^{137} \mathrm{Cs}$ grain: straw activity ratios in barley and wheat plants were reported earlier ( $\mathrm{Wu}$ et al. 2009). The results suggested that ${ }^{137} \mathrm{Cs}$ plant uptake is better described when ratio of ${ }^{137} \mathrm{Cs} / \mathrm{K}$ in soil is considered, because an increment of $\mathrm{K}$ concentration in soil inhibits ${ }^{137} \mathrm{Cs}$ uptake by the plant. This observation suggests an inhibitory effect of potassium on radiocesium uptake by plant roots. In addition, the concentration of radiocesium remained in soil contaminated with ${ }^{137} \mathrm{CsCl}$ was found to range between 142.91 and $354.57 \mathrm{~Bq} / \mathrm{kg}$ soil, showing an approximately $40 \%$ variation between the upper and lower limits of the range. While, the average values of radiocesium concentration remained in soil was 192.9, 226.2 and $267.99 \mathrm{~Bq} / \mathrm{kg}$ soil for 125 and $250 \mathrm{~kg} / \mathrm{K} \mathrm{kg}$, respectively.

Table $1 .{ }^{137} \mathrm{Cs}$ concentration $(\mathrm{Bq} / \mathrm{kg} \mathrm{DW})$ in barley plant parts, total biomass and soil as affected by ${ }^{137} \mathrm{CsCl}$ concentration $(\mathrm{mM})$ and potassium levels ( $\left.\mathrm{kg} / \mathrm{ha}\right)$.

\begin{tabular}{|c|c|c|c|c|c|c|}
\hline \multirow{2}{*}{\multicolumn{2}{|c|}{$\begin{array}{c}{ }^{137} \mathrm{CsCl} \text { concentration } \\
(\mathrm{mM})\end{array}$}} & \multicolumn{5}{|c|}{$\mathrm{K}$ rate $(\mathrm{kg} / \mathrm{ha})$} \\
\hline & & \multirow{2}{*}{\multicolumn{2}{|c|}{ Roots }} & \multirow{2}{*}{\multicolumn{2}{|c|}{125}} & \multirow[t]{2}{*}{250} \\
\hline & & & & & & \\
\hline & 0.01 & & 37.90 & & 25.19 & 15.20 \\
\hline & 0.10 & & 82.20 & & 79.10 & 34.82 \\
\hline \multirow{2}{*}{\multicolumn{2}{|c|}{ Mean }} & & 60.05 & & 52.15 & 25.01 \\
\hline & & \multicolumn{2}{|c|}{ Straw } & & & \\
\hline & 0.01 & & 15.12 & & 6.73 & 2.70 \\
\hline & 0.10 & & 40.59 & & 28.00 & 8.81 \\
\hline \multirow{2}{*}{\multicolumn{2}{|c|}{ Mean }} & & 27.81 & & 17.37 & 5.76 \\
\hline & & \multicolumn{2}{|c|}{ Grains } & & & \\
\hline & 0.01 & & 4.07 & & 1.60 & 0.40 \\
\hline & 0.10 & & 16.30 & & 8.90 & 1.80 \\
\hline \multirow{2}{*}{\multicolumn{2}{|c|}{ Mean }} & & 10.19 & & 5.25 & 1.10 \\
\hline & & \multicolumn{2}{|c|}{ Total biomass } & & & \\
\hline & 0.01 & & 57.09 & & 32.52 & 18.30 \\
\hline & 0.10 & & 39.09 & & 116.00 & 45.43 \\
\hline \multirow{2}{*}{\multicolumn{2}{|c|}{ Mean }} & & 98.09 & & 74.26 & 31.82 \\
\hline & & \multicolumn{2}{|c|}{ Soil } & & & \\
\hline & 0.01 & & 142.91 & & 166.48 & 181.70 \\
\hline & 0.10 & & 260.91 & & 284.00 & 354.57 \\
\hline & Mean & & 192.91 & & 225.24 & 267.99 \\
\hline$\overline{\mathrm{LSD}_{0.05}}$ & Roots & Straw & Grains & Total biomass & Soil & \\
\hline $\mathrm{K}$ & 5.85 & 8.33 & 7.57 & 8.83 & 3.83 & \\
\hline Cs & 20.22 & 8.17 & 11.56 & 12.25 & 15.95 & \\
\hline $\mathrm{K}^{*} \mathrm{Cs}$ & 0.907 & 11.02 & 2.24 & 4.60 & 4.70 & \\
\hline
\end{tabular}

${ }^{137} \mathrm{Cs}$ transferred to roots from soil has a TF average value of 0.29 , and a range between 0.26 and 0.31 with increasing ${ }^{137} \mathrm{CsCl}$ concentration from 0.01 to $0.1 \mathrm{mM}$, respectively (Table 2). TF average value transferred from soil-to-total biomass was 0.47 , with a range of $0.40-0.53$, for the same sequence. While, transport or translocate of ${ }^{137} \mathrm{Cs}$ as an average values from root to straw, straw to grain and root to grain were $0.45,0.33$ and 0.16 , respectively at $0 \mathrm{~kg} / \mathrm{K}$ ha. 
It was observed that radiocesium translocate values from root to straw was higher than from root to grains. It means that more than 55 and $67 \%$ of ${ }^{137} \mathrm{Cs}$ accumulated in the roots is due to its less translocation to straw and grains, respectively. In the same time, $33 \%$ of ${ }^{137} \mathrm{Cs}$ content in straw was transported to grains. In this regard, Sachdev et al. (2006) indicated that the highest level of fertilizer reduced TFs to cereals by up to $33 \%$ and to cabbage by about $50 \%$. Similarly, Schuller et al. (2006) found that K fertilization reduced Cs TFs to Swiss chard, sweet corn and cabbage by $30-75 \%$ in one (the Umbric Andosol is a silty loam soil) and $60-75 \%$ in another (Dystric Fluvisol is a loam soil). So, transfer of ${ }^{137} \mathrm{Cs}$ from roots to straw or grains further depends on the biological properties of plant species, and not merely on the rate of the above-ground biomass growth. Higher plants possess the ability for accumulation of ${ }^{137} \mathrm{Cs}$ in roots or shoots, where the TFs of ${ }^{137} \mathrm{Cs}$ in plants are often less than 1 (Godyn et al. 2016). Increasing $\mathrm{K}$ rates from 125 to $250 \mathrm{~kg} / \mathrm{ha}$ markedly reduced the TFs of ${ }^{137} \mathrm{Cs}$ from soil-to-roots by about 25 and $68 \%$ and from

Table 2. Transfer factor values for ${ }^{137} \mathrm{Cs}$ as affected by $\mathrm{K}(\mathrm{kg} / \mathrm{ha})$ fertilization and ${ }^{137} \mathrm{Cs}(\mathrm{mM})$ levels added to sand soil cultivated by barley plants.

\begin{tabular}{|c|c|c|c|c|c|c|}
\hline \multirow{2}{*}{\multicolumn{2}{|c|}{$\begin{array}{l}{ }^{137} \mathrm{CsCl} \text { conc. } \\
(\mathrm{mM})\end{array}$}} & \multicolumn{5}{|c|}{ Rate of $\mathrm{K}$ applied $\mathrm{kg} / \mathrm{ha}$} \\
\hline & & & 0 & & 125 & 250 \\
\hline \multicolumn{7}{|c|}{ Soil to root } \\
\hline \multicolumn{2}{|l|}{0.01} & & 0.26 & & 0.15 & 0.084 \\
\hline \multicolumn{2}{|l|}{0.10} & & 0.31 & & 0.28 & 0.098 \\
\hline \multicolumn{2}{|l|}{ Mean } & & 0.29 & & 0.22 & 0.091 \\
\hline \multicolumn{7}{|c|}{ Root to straw } \\
\hline \multicolumn{2}{|l|}{0.01} & & 0.40 & & 0.27 & 0.18 \\
\hline \multicolumn{2}{|l|}{0.10} & & 0.49 & & 0.35 & 0.25 \\
\hline \multicolumn{2}{|l|}{ Mean } & & 0.45 & & 0.31 & 0.22 \\
\hline \multicolumn{7}{|c|}{ Root to grains } \\
\hline \multicolumn{2}{|l|}{0.01} & & 0.11 & & 0.06 & 0.03 \\
\hline \multicolumn{2}{|l|}{0.10} & & 0.20 & & 0.11 & 0.05 \\
\hline \multicolumn{2}{|l|}{ Mean } & & 0.16 & & 0.09 & 0.04 \\
\hline \multicolumn{7}{|c|}{ Straw to grains } \\
\hline \multicolumn{2}{|l|}{0.01} & & 0.27 & & 0.24 & 0.14 \\
\hline \multicolumn{2}{|l|}{0.10} & & 0.40 & & 0.32 & 0.20 \\
\hline \multicolumn{2}{|l|}{ Mean } & & 0.33 & & 0.28 & 0.17 \\
\hline \multicolumn{7}{|c|}{ Soil to biomass } \\
\hline \multicolumn{2}{|l|}{0.01} & & 0.40 & & 0.19 & 0.10 \\
\hline \multicolumn{2}{|l|}{0.10} & & 0.53 & & 0.40 & 0.13 \\
\hline \multicolumn{2}{|l|}{ Mean } & & 0.47 & & 0.30 & 0.12 \\
\hline $\mathrm{LSD}_{0.05}$ & Soil-root & Root-straw & Root-grains & Straw-grains & Soil- biomass & \\
\hline K & 0.066 & 0.16 & 0.082 & 0.13 & 0.15 & \\
\hline Cs & 0.34 & 0.051 & 0.075 & 0.03 & 0.11 & \\
\hline $\mathrm{K}^{*} \mathrm{Cs}$ & 0.011 & 0.11 & 0.044 & 0.04 & 0.12 & \\
\hline
\end{tabular}

soil-to-total biomass by about 36 and $74 \%$ less than the corresponding control for 125 and $250 \mathrm{~kg}$ $\mathrm{K} / \mathrm{ha}$, respectively (Table 2). The present results are consistent with previous findings revealed that the transfer factor of ${ }^{137} \mathrm{Cs}$ tended to decreased with increasing concentrations of potassium in 
soils (Kratochvil et al. 1986). Also, Rosén et al. (2011) reported that K fertilizers can reduce the radio cesium transfer by about $40-60 \%$, being more successful in the lower $\mathrm{K}^{+}$available in soil. The reduction effects are lasting and observable during long periods, after fertilization (Rosén et al. 2011). The inhibitory effects of $\mathrm{K}$ fertilizer on ${ }^{137} \mathrm{Cs}$ transfer from soil to barley grain are in agreement with the results obtained by Bogdevitch et al. (2008).

Application of $0.01 \mathrm{mM}^{137} \mathrm{CsCl}$, in combination with $250 \mathrm{~kg} \mathrm{~K} /$ ha markedly decreased the translocation of ${ }^{137} \mathrm{Cs}$ to grains from straw and roots by about 51.52 and $48 \%$, respectively. While, it was about $48.89 \%$ in ${ }^{177} \mathrm{Cs}$ transport from root-to-straw. But, at $0.1 \mathrm{mM}^{137} \mathrm{Cs}$, the reduction in ${ }^{137} \mathrm{Cs}$ transport from straw and roots to grains was 75 and 59\%, respectively. On the other hand, for the previous treatment, the decreasing in ${ }^{137} \mathrm{Cs}$ transfer from soil either to straw or total biomass plants recorded about 67 and $75 \%$, respectively. It means that about 33 and $25 \%$ from the total concentration of ${ }^{137} \mathrm{Cs}$ in sand soil transfer to roots and total biomass, respectively. Whereas, at the low level of $\mathrm{K}(125 \mathrm{~kg} \mathrm{~K} / \mathrm{ha})$ with $0.01 \mathrm{mM}^{137} \mathrm{Cs}$, the reduction in radiocesium transfer from soil to roots and to total biomass was 42 and $52 \%$ less than corresponding control, respectively. While, with increasing the concentration of ${ }^{137} \mathrm{Cs}\left(0.1 \mathrm{mM}{ }^{137} \mathrm{Cs}\right)$ added to soil at the same rate of $\mathrm{K}$, the reduction in ${ }^{137} \mathrm{Cs}$ was 9 and $24 \%$ lower than control for the previous sequence. Fertilizing the soil with $\mathrm{K}^{+}$ions reduce cesium transfer into plants by as much as 60\% (Lembrechts 1993). Despite its smaller diameter ( $\mathrm{K} 0.33$ and $\mathrm{Cs} 0.31 \mathrm{~nm}$ in radius), $\mathrm{Cs}^{+}$is taken up at a much lower rate than $\mathrm{K}^{+}$. Obviously, factors other than ionic diameter are involved in the uptake regulation; one of them being the affinity for membrane bound carriers, or channels (Marschner and Marschner 2012), also reported that high K concentration in soil acts as inhibitor and prevents Cs uptake. It is well accepted that $\mathrm{K}^{+}$uptake by plant roots is a consequence of two different, but parallel, mechanisms present on plasma membranes: (a) high-affinity energized transporter system and, b) low-affinity mechanism, usually associated with ion-channels.

Table 3. Cs/K discrimination factor values, in barley grown on sand soil.

\begin{tabular}{ccccc}
\hline${ }^{137} \mathrm{Cs} \mathrm{Cl} \mathrm{conc.(mM)}$ & \multicolumn{4}{c}{ Rate of K applied kg/ha } \\
\cline { 2 - 5 } & 0 & \multicolumn{3}{c}{125} \\
\hline & & $\mathrm{Cs} / \mathrm{K}$ & \\
0.01 & 0.09 & & 0.075 & 0.050 \\
0.10 & 0.142 & & 0.095 & 0.081 \\
Mean & 0.120 & & 0.088 & 0.026 \\
\hline
\end{tabular}

Due to the competitive interactions that occurred between Cs and $\mathrm{K}$ ions, the discrimination factor (DF), which is often used to evaluate a plant's efficiency to absorb nutrients from soil, was additionally estimated (Table 3). The obtained $\mathrm{Cs} / \mathrm{K}(\mathrm{DF})$ values were found to range from 0.05 to 0.141 and varied among the treatments. ${ }^{137} \mathrm{CsCl}$ increased from 0.095 to 0.142 with increasing the applied ${ }^{137} \mathrm{CsCl}$ concentrations from 0.01 to $0.1 \mathrm{mM}$. While, it was found to reduce from 0.120 to 0.088 and 0.026 with rates of 0,125 and $250 \mathrm{~kg} \mathrm{~K} / \mathrm{ha}$, respectively. Combined treatments of ${ }^{137} \mathrm{CsCl}$ and $\mathrm{K}$ fertilization, resulted in reduction $\%$ in $\mathrm{Cs} / \mathrm{K}$ discrimination factor by 21 and $47 \%$ at $0.01 \mathrm{mM}{ }^{137} \mathrm{CsCl}$ concentration; while it was 33 and $43 \%$ at $0.1 \mathrm{mM}{ }^{137} \mathrm{CsCl}$ concentration less than corresponding control treatment when barley plants fertilized with $\mathrm{K}_{2} \mathrm{SO}_{4}$ at the rates 125 and $250 \mathrm{~kg} \mathrm{~K} / \mathrm{ha}$, respectively. The discrimination factor was in all cases below unity, indicating that $\mathrm{K}$ was better assimilated by barley plants than radiocesium. The present results are consistent with the results obtained by Niesiobedzka and Krajewska (2009). Also, Smolders et al. (1996) reported that the DF values ranged from 0.04 and 0.26 in spring wheat plants grown at different soil $\mathrm{K}$ 
concentrations. Thus, it is possible that plants reject $\mathrm{Cs}^{+}$ions and absorb $\mathrm{K}$ ions, which are necessary for their growth. Moreover, the DF values indicated that $\mathrm{K}$ appears to be one of the main factors influencing plant mobility of Cs and behaves not only as a competitor to Cs ions, but also as an effective inhibitor of Cs uptake by plants (Table 3 ).

Results showed that root ${ }^{137} \mathrm{Cs}$ uptake from soil solution markedly decreased with increasing soil $\mathrm{K}$ application. At high dose, $\mathrm{K}(250 \mathrm{~kg} / \mathrm{ha})$ exhibits counteracting effects on Cs availability because it can mobilize exchange or water soluble reactions, while it also blocked ${ }^{137} \mathrm{Cs}$ through cation ${ }^{137} \mathrm{Cs}$ ion uptake by the roots. It is retarded by potassium application added to soil. In the root, cesium occurs mainly in the form of $\mathrm{Cs}^{+}$, as it is being supplied with the addition of ${ }^{137} \mathrm{CsCl}$ to soil. Barley plants grown on ${ }^{137} \mathrm{Cs}$ - artificially contaminated soil for 150 days showed a low soil-to-plant transfer factor (TF). Potassium application to sand soil was effective at the 125 and $250 \mathrm{~kg} \mathrm{~K} / \mathrm{ha}$ level. Application of $250 \mathrm{~kg} \mathrm{~K} /$ ha resulted in $(51 \%)$ reduction in ${ }^{137} \mathrm{Cs}$ transfer straw and up to $(75 \%)$ to grain. The reduction in ${ }^{137} \mathrm{Cs}$ transfer to plant was markedly related to the amount of $\mathrm{K}$ content in organs. The TFs and $\mathrm{Cs} / \mathrm{K}$ discrimination factor (DFs) were below unity, show inhibitory influence of $\mathrm{K}$ on translocation of ${ }^{137} \mathrm{Cs}$ process from soil to plant. It could be recommended that repeated annual potassium fertilization was an effective and practicable counter measure for reducing contamination of agricultural products by radiocesium. The major differences in the ${ }^{137} \mathrm{Cs}$ root uptake and further translocation into above-ground biomass are closely related to the level of soil radioactive pollution and $\mathrm{K}$ fertilization that should be considered in land use policy. The results showed that ${ }^{137} \mathrm{Cs}$ from roots and straw to grains in the presence of potassium fertilization is safe in environmental, also safe on animal and human.

\section{References}

Bogdevitch I and Mikulich V 2008. Yield and quality of spring wheat grain in relation to the P status of Luvisol loamy sand soil and fertilization. Zemès Ukio Mokslai. 15(3): 47-54.

Chino M, Nakayama, H, Nagai H, Terada H, Katata G and Yamazawa H 2011. Preliminary estimation of release amounts of ${ }^{131} \mathrm{I}$ and ${ }^{137} \mathrm{Cs}$ accidentally discharged from the Fukushima Daiichi nuclear power plant into the atmosphere. J. Nucr. Sci. and Tech.48: 1129-1134.

Ciuffo L, Velasco H, Belli M and Sansone U 2003. ${ }^{137}$ Cs soil-to-plant transfer for individual species in seminatural grassland. Influence of potassium soil content. J. Radiation Research. 44: 277-283. com/theory /2011/fukushima-radiation-comparison-map/

Covell DF1959. Analytical Chemistry 31: 17-85.

Ehlken S and Kirchner G 2002. Environmental processes affecting plant root uptake of radioactive trace elements and variability of transfer factors data: a review. J. Envi Radioactivity, Oxford: Elsevier Science Ltd. 58: 97-112.

Godyn P, Dołhanczuk-Srodka A, Ziembik Z andMoliszewska E 2016. Influence of K on the transport of Cs137 in soil-plant root and root-leaf systems in sugar beet. J. Radioanal Nucl. Chem. 307: 325-331.

Hamada N and Ogino H 2012. Food safety regulations: what we learned from the Fukushima nuclear accident. J. Environ. Radio. Act. 111: 83-89.

IAEA 2009. Quantification of radionuclide transfer in terrestrial and freshwater environments for radiological assessments. IAEA-TECDOC-1616. Vienna.

IAEA 1994 "Handbook of Parameter Values for the Prediction Of Radionuclide Transfer in Temperate Environments", A Guide Book Technical Report Series No. 364. Vienna.

International Union of Radioecologists (IUR) 1994. Handbook of parameter values for the prediction of radionuclide transfer in temperate environments. Technical reports series no. 364. Vienna: International Atomic Energy Agency (IAEA).

Kobayashi NI, Sugita R, Nobori T, Tanoi K and Nakanishi TM 2016. Tracer experiment using ${ }^{42} \mathrm{~K}^{+}$and ${ }^{137} \mathrm{Cs}^{+}$revealed the different transport rates of potassium and Cesium within rice roots. Funct. Plant Biol. 43: 151-160. 
Kratochvil B, John D and Dennis N 1986. Evaluation of homogeneity of certified reference materials by instrumental neutron activation analysis. Anal. Chem. 58: 102-108.

Lembrechts J 1993. A review of the literature on the effectiveness of chemical amendments in reducing the soil-to-plant transfer of radio strontium and radiocaesium. Sci. Total Environ. 137: 81.

Marschner P and Marschner's 2012. Mineral Nutrition of Higher Plants. Academic Press is an imprint of Elsevier, Third edition.

Niesiobedzka K and Krajewska E 2009. The influence of the exchangeable potassium and K-40 on the migration of the radiocaesium Cs-137 from the soil solution into the plants in Polish. Ochrona S 'rodowiska i Zasobo'w Naturalnych. 40: 262-270.

Page AL, Miller RH and Keeney DR 1982. Method of Soil Analysis. Part 2. American Society for Soil Science, Inc. Madison, Wisconsin, U.S.A.

Perepelyatnikov G, Perepelyatnikova L, Ivanova T,Kalynenko L, Grytsyuk N andZhurba M 2007. Radiological efficiency of agricultural countermeasures applied in radio contaminated fields. J. Environ. Eng. Landsc. 15: 243-252.

Robison WL, Brown PH, Stone EL, Hamilton TF, Conrado CL and Kehl S 2009. Distribution and ratios of ${ }^{137} \mathrm{Cs}$ and $\mathrm{K}$ in control and K-treated coconut trees at Bikini Island where nuclear test fallout occurred: Effects and implications. J Environ Radioact. 100: 76-83.

Rosén K, Vinichuk M, Nikolova I and Johanson K 2011. Long-term effects of single potassium fertilization on ${ }^{137} \mathrm{Cs}$ levels in plants and fungi in a boreal forest ecosystem. J. Environ. Radio act. 102: 178-184.

Sachdev P, Sachdev MS and Manjaiah KM 2006. The classification of Indian soils on the basis of transfer factors of radionuclides from soil to reference plants IAEA-TECDOC-1497, VIENNA.89-100.

Schuller P, Bunzl K, Voigt G, Krarup A and Castillo A 2006. Soil to crops transfer of radiocaesium and strontium in different allophanic soils from the lake region, CHILE . IAEA-TECDOC.VIENNA. 1497: 139-144.

Smolders E, Ki booms L, Buysse J and Merckx R 1996. ${ }^{137}$ Cs uptake in spring wheat (Triticum aestivum L. Cv. Tonic) at varying K supply. I: A potted soil experiment. J. Plant and Soil. 18: 205-209.

Smolders E, Sweeck L, Merckx R and Cremers A 1997. Cationic interactions in radiocesium uptake from solution by spinach. J. Environ. Radioact. 34: 161-170.

Waegeneers N, Sauras-Yera T, Thiry, Y, Vallejo VR, Smolders E and Madoz Escande C 2009. Plant uptake of radiocesium from artificially contaminated soil monoliths covering major European soil types. J. Environ. Radioact. 100: 439-444.

Wu HB, Tang SR, Zhang XM, Guo JK, Song, ZG, Tian SA and Smith DL 2009. Using elevated $\mathrm{CO}_{2}$ to increase the biomass of a Sorghum vulgare var. Sudanense hybrid and Trifolium pratense L. and to trigger hyper accumulation of cesium. J. Hazard. Mater. 170: 861-870.

Yoshida S, Muramatsu Y, Dvornik AM, Zhuchenko TA and Linkov I 2004.Equilibrium of radiocesium with stable cesium within the biological cycle of contaminated forest ecosystems. Journal of Environment Radioactivity, Oxford: Elsevier Science Ltd. 75: 301-313.

(Manuscript received on 24 September, 2018; revised on 29 December, 2018) 